Article

\title{
The Averted Gaze: Audre Lorde's Zami and the Death of Emmett Till
}

\section{Rachel Watson}

Department of English, Howard University, Washington, DC 20059, USA; rachel.watson@howard.edu

Received: 29 June 2019; Accepted: 2 August 2019; Published: 9 August 2019

\begin{abstract}
This essay considers Audre Lorde's Zami: A New Spelling of My Name (1982) as an example of the neoliberal turn to memoir that both complicates and exemplifies important aspects of the relationship between literary form and ideological expressions of racial and sexual identity. By examining a hitherto un-noted omission from Lorde's memoir, the death of Emmett Till, this essay illuminates the political significance behind Lorde's choice to narrate Till's death in the form of a poem while conspicuously omitting it from her prose memoir. Incorporating a broader selection of Lorde's work, and comparative analysis with other poetic responses to Till's death, this essay shows through this example how the intense personalization of an historical event can formalize the embodiment of an essentialized, and thus timeless, racial identity. As such, Lorde's work demonstrates how literary form can both communicate and obscure paradoxical aspects of contemporary racial ideology by rationalizing the embodiment of racial difference in the post-Civil Rights world.
\end{abstract}

Keywords: Audre Lorde; Emmett Till; African American literature; African American poetry; memoir; autobiography; feminism; sexuality; race; identity

In becoming forcibly and essentially aware of my mortality, and of what I wished and wanted for my life, however short it might be, priorities and omissions became strongly etched in a merciless light, and what I most regretted were my silences. Of what had I ever been afraid? ... Death ... is the final silence. And that might be coming quickly, now, without regard for whether I had ever spoken what needed to be said, or had only betrayed myself into small silences, while I planned someday to speak, or waited for someone else's words.

Audre Lorde, from "The Transformation of Silence into Language and Action" 1

Like so many other vital pieces of information from my childhood, I was supposed to know it without being told.

Audre Lorde, from Zami: A New Spelling of My Name ${ }^{2}$

\section{Introduction: Narrativizing Identity and the Omissions of History}

In Audre Lorde's work, the force of silence appears as a recurring and varied theme. Many of Lorde's most powerful and evocative passages depict a battle against the devastating effects of a life withheld, of a natural voice stifled by the fearful effects of hegemony. As the story of a young life examined retrospectively from a confrontation with her own mortality, Lorde's "biomythography" Zami: A New Spelling of My Name (1982) is composed in a manner fitting the complicated nature of what it often takes to be its greatest adversary: silence within, and silence without. In Zami, Lorde responds to this adversary not only with words, but-in an iteration of the ideological call to arms for

Sister Outsider, 41.

Audre Lorde, Zami: A New Spelling of My Name (Berkeley: The Crossing Press, 1982) p. 69. 
which she became famous-by taking up the master's tools to dismantle the master's house, deploying various strategic silences of her own.

As such, Lorde's Zami complicates a common assessment of the late-twentieth-century turn to memoir, as a neoliberal symptom of the deepening commitment to personal identity-a commitment that some contend amplifies rather than meaningfully contests the structural forces that reproduce the very inequalities such assertions of identity can often purport to fight. ${ }^{3}$ Even as it appears to exemplify such a turn, in its own way Lorde's Zami can also be seen as of a piece with the kind of aspiration toward "impersonality" advocated by a longer tradition of American writers, from the Transcendentalists to the modernists, in which "personal" material is deemed only worthy of inclusion insofar as it speaks to that which is "universal." ${ }^{4}$ But more relevant to its time, and perhaps more importantly, Zami also demonstrates a paradoxical picture of the importance of self-ownership in an increasingly neoliberal age, by rejecting identity-as-commodity in favor of a self-forged vision that protects her from the violent assaults of the status quo. That is to say, Zami emerges at a moment just before personal identity became equivalent with personal branding, when one could still imagine an insistence on narrating one's truth regarding engagements with ascriptive identity as undertaking a transcendent, radical act.

However, to claim for Zami a transcendence above identity discourse would seem to place it at odds with the memoir form itself-particularly one that predicates its significance, and urgency, on asserting the importance of categories of identity that affirmatively resist the norms of the status quo. After all, as Lorde articulated in an interview published while still writing Zami, the very inspiration behind the project was to affirm the legitimacy of a specifically "intersectional" identity: one that was African American, lesbian, and professionally aligned with literary studies:

I call it a biomythography. I wrote the book out of a need I heard in the black women's community—-that's how it first started. Barbara Smith said to me: 'I'm a black lesbian feminist literary critic and I don't know whether it's possible to be a black lesbian feminist literary critic and survive.' When I heard that-just about five years ago-I thought, 'Oh boy, I've got to start writing some of that stuff down. She needs to know that yes, it is possible.' And it grew from that. [ ... ] I learned a lot in doing it, but then again I learned a lot in learning how to write prose, a different kind of thinking. ${ }^{5}$

As such, for Lorde, the project's overt commitment to identity required a pastiche of genres in order to formalize the relationship to self she sought to evoke for the sake of affirming an identity that did not, on its own, feel safe in the world: the "biomythography", part highly historicized memoir, part timeless creation myth. As an aspect of this, the project also required grappling with a key problem that remains with us today, and one that puts her work in a certain alignment with a history of radical thinkers that stretches back well past the neoliberal turn: how to write from the perspective of the individuated self in such a way that will be affirming and resonant for the individual reader, such that one's work might forge a sense of community while also asserting a political value beyond the narrative of the individual. One might say that in this way-both formally and politically-Lorde's work stands in a clear lineage with African American women's life-writing, from the slave narratives and spiritual confessions of the nineteenth century, to migration narratives of the mid-twentieth, to the autobiographical writing of second- and third-wave feminisms. ${ }^{6}$ In each of these iterations, racial and

3 See for example, various work by Walter Benn Michaels, including The Trouble with Diversity, (Michaels 2017). For the argument along these lines that specifically concerns African American literature, see (Warren 2011). For a more recent appraisal of women's life writing in particular in the context of neoliberal hegemony, see (Gilmore 2017, pp. 85-117).

4 (Buell 2016, p. 269), passim. On the relation of narrativization of personal affect and the neoliberal turn see (Smith 2015); on the specific political relevance of the memoir form to this moment, see (Worden 2017).

5 (Lorde et al. 1982), interview from Off Our Backs, April 1982, p. 2.

6 For one study of African American women's spiritual narratives of the nineteenth century, see (Moody 2001). Regarding the political and historical significance of African American life writing more generally, see (Franklin 1995; Andrews 1986); 
sexual inequality writ large appear to imbue literary form with something like an "indexical" register, such that asserting the particularized narrative voice correlated at various moments to the assertion of political personhood-or even that of full humanity-worthy of recognition in the public sphere. As such, despite its mid-century temporal scope, the aim and structure of Lorde's 1982 memoir can be understood as participating in a much longer tradition of African American autobiography, and in the kind of formal experimentation demanded by such political aims. For authors forced to bear the unequal norms of socially-ascribed identity, the memoir form emerged early on as an elastic mode, one that could demonstrate liberation from the hierarchical hegemonies of essentialized personhoods.

But through Zami, Lorde also formalizes the very question that she famously posed: can we, after all, dismantle the master's house by using the master's tools? (Lorde 1984) That is to say, can an assertion of the same kind of normative identity-discourse that had been used to silence and thus deform the development of individual consciousness become instead a means of political empowerment? More precisely, the formal choices that structure Zami seem to imply a standing question animating contemporary narratives of identity more broadly: how does the racialized individual plausibly locate herself in historical time, without abandoning the notion of racial difference altogether? The essay that follows considers such questions through a reading of Lorde's Zami, concerning both the role of silence in the protagonist's personal development and the significance of a critically overlooked and yet conspicuous omission from its text: that of the politically and socially cataclysmic death of Emmett Till in August 1955.

Though absent from her prose memoir, Till's death and its powerful effect appear elsewhere in Lorde's poetry, speeches, essays, and interviews, including the interview cited above. Held just before the publication of Zami, at the event Lorde read "Afterimages," her long poem that memorialized Till's death, reaching back almost 30 years to evoke the experience of being visually assaulted by the photographs of Till's mutilated corpse circulating in mass media during the summer of 1955. After the reading, Lorde and Fran Moira discussed the difficulties that attend a white woman and a black woman discussing race. In response, Moira noted "Afterimages" as a piece that evokes what Lorde had described as differences between white and black women that are rooted in both history and in the body. Lorde replied, "A lot of it is history that we have come through; a lot of it is centered within me, within you". ${ }^{7}$

Though Lorde's assertion of such "centering" elicited unquestioned assent, locating social and political history in the body invites complex, and paradoxical, political entailments. In Lorde's work, we can see one way in which such complexities could be smoothed over by virtue of authorial decisions regarding literary form, and by the treatment of historical content. For Lorde, the death of Emmett Till could not be represented in prose, nor even in the memoir itself, but demanded a free verse poem instead. More specifically, it was the encounter with the representation of his murder, and the proliferation of the image of his corpse, that Lorde wanted to narrate as a personal experience, but did not want to include in the "biomythography". The combined appearances and disappearances in her work of this highly politicized murder illuminate aspects of how Lorde's own racial consciousness developed during both the time covered by Zami, approximately 1924 to 1956, and during the time of its publication, 1982. But it also suggests broader insights into the workings of racial ideology itself post-Jim Crow-particularly how it could appear to be both independent of and utterly derived from the contingencies of its recent history, at the same time.

regarding the migration narrative of the twentieth century, see (Griffin 1995). For a more recent consideration of the genre and its theoretical implications for a diasporic black identity, see (Alabi 2005). Regarding the ongoing historical and political significance of the form for African-American women in particular, see (McKay 1995).

7 (Lorde et al. 1982), interview from Off Our Backs, April 1982, p. 3. 


\section{A Memoir of Identity in the Era of Civil Rights}

The story of Zami begins in the year 1924, upon Audre's parents' arrival in the United States, and ends in approximately the late 1950s, as Audre reaches her early twenties and as the American Civil Right Movement begins in earnest. ${ }^{8}$ In fact, Zami ends at the movement's beginning. The lunch counter sit-ins throughout the southeast in early 1960, the rising prominence of Malcolm X and the National of Islam in 1961, along with the attack on the Freedom Riders in the same year, are just a few examples of events that immediately followed the approximate year in which Zami leaves off. As Anna Wilson and others have noted, Lorde includes several historical markers throughout the narrative. ${ }^{9}$ The effects of the Great Depression loom large in her childhood, through vivid descriptions of Harlem in the 1930s, as does her personal response to the death of the Rosenbergs and the palpable effects of McArthyism (Lorde 1982, pp. 10, 17, 148, 121, 149, respectively). Though Lorde describes a childhood experience of segregation in Washington, DC, and her cynical reaction to the Supreme Court decision to desegregate schools, Audre's exposure to and reflections upon many of the now iconic images and events from the struggle for civil rights in the 1950s are withheld from her readers. In addition to the omission of Till, Lorde also omits mention of the arrest of Rosa Parks in 1955, the ensuing Montgomery Bus Boycott in the same year, and the National Guard enforced desegregation of Little Rock High School in September of 1957. Of these historical omissions, the lynching of Emmett Till stands out as an intentionally created lacuna. Unlike the others, it is not excluded from the narrative without a trace, but is instead written around, so that the shape of its absence occupies a pivotal place in the narrative of Audre's journey to self.

In August 1955, 14-year-old Emmett Till was kidnapped and murdered in Money, Mississippi by two white men who were later acquitted of all charges. The murder was followed in almost immediate succession by some of the most publicized and subsequently defining events of the modern Civil Rights Movement in the United States. As many historians have noted, the galvanizing impact of Till's death could be traced in large part to the photographs of his mutilated body, taken at his mother's insistence by the black press at the public, open-casket memorial service in Chicago. It is hard to overstate the effect of Till's death on the popular conscience and the ubiquity of its story in popular media at the time; though some historians have since argued that the claims are too sweeping, Till's death-and specifically, the mass circulated photos of his corpse-has nonetheless been characterized as the catalyst of the American Civil Rights Movement that followed. Though subsequently distributed through many news publications, Jet magazine was the first to carry the gruesome photographs. ${ }^{10}$

In light of the magnitude of this event, it is striking that Chapter 27 of Zami begins with Lorde orienting her readers at such a significant moment in historical time: "In that golden summer of 1955 [ ... ]" (Lorde 1982, p. 210). The following paragraph begins with an unexpected reference to Jet magazine: "Life had so many different pieces. Jet was a girlie magazine trying to be a Black newsmagazine [ ... ]" (Lorde 1982, p. 210) In the same passage, Lorde goes on to describe her relationship to the magazine:

8 Though an autobiography of sorts, the historical Audre Lorde as writer is not interchangeable with the protagonist of Zami. For clarity, through this essay, I will borrow a distinction from Anna Wilson, in which "Audre" refers to the protagonist of Zami, and "Lorde" refers to the author herself.

9 (Wilson 2001) writes: "Zami is also [in addition to being a personal narrative] densely situated in a web of references to historical events—-the Rosenberg executions, the Supreme Court ruling on desegregation [ ... ] which [ ... ] lend it verisimilitude and suggest that Lorde is intending to conjure a specific or cultural moment". (p. 99) While Wilson does not mention the the historical absences, she goes on to discuss Lorde's "fabrications," particularly her "rewrit[ing] the [African American] genealogy so that it includes her". (p. 109) I suggest that her conspicuous omissions contribute to such constructive fabrications.

10 Various historians and artists have since memorialized Till's death and elaborated on the historical ramifications of the ensuing trial and circulation of the photos. For a gloss on significant literary interpretations and reflections, see (Metress 2003). For key historical accounts, including that of Till's mother Mamie Till-Mobley, see (Till-Mobley and Benson 2003; Rubin 1996; Whitfield 1988). On Mamie Till's response in particular and its political and ideological significance, see (Smith 2008). On the significance of the media and photographic representation of Till's murder, particularly in the context of the longer history of American lynching documentation and circulation, see Goldsby. 
Jet was a girlie magazine trying to be a black newsmagazine which I borrowed from my brother-in-law Henry on my infrequent visits to the Bronx, read avidly on the long subway ride downtown, and then surreptitiously dropped onto the next seat as I got off. When I mentioned at the library that I wrote poetry ... (Lorde 1982, p. 210) (my emphasis)

In each of these moments, Lorde pivots suddenly from one topic to another, juxtaposing thoughts and images that would appear to have no associative relationship: from the abstracted reference "so many pieces" of life, to Jet magazine; from dropping an issue of Jet on a train downtown in the summer of 1955, to Lorde mentioning at the library that she wrote poetry. Through the careful structure of these otherwise disconnected moments, Lorde evokes the ghostly presence of Till's murder-more precisely, the photograph of his corpse-by choosing not to render it at all. In this gentle but purposeful omission, Lorde responds to the grotesqueness she felt at the proliferation of the image that summer, a feeling she illuminated in her poem written simultaneous with Zami, "Afterimages". By not including a narration of the image in Zami, Lorde refuses to participate in the sacrifice of his body to public consumption. The move resonates with Gwendolyn Brooks's response to Mamie Till-Mobley's voluntary sacrifice of the privacy of her grief, in Brooks's spare and formally careful poem "The Last Quatrain of the Ballad of Emmett Till," in which the poet's perspective hovers above Till's mother, at a respectful and yet intimately protective distance:

(after the murder,

after the burial)

Emmett's mother is a pretty-faced thing;

the tint of pulled taffy.

She sits in a red room, drinking black coffee.

She kisses her killed boy.

And she is sorry.

Chaos in windy grays

through a red prairie. (Brooks 1960)

Here, Brooks uses poetic form to refuse the invasive proximity of realist representation. Coming after the previous long poem, "A Bronzeville Mother Loiters in Mississippi. Meanwhile, a Mississippi Mother Burns Bacon," which offered an unsparingly quotidian view of Till's white woman accuser, the "Last Quatrain" contrasts sharply with this preceding perspective. As a consequence of the contrast, the simple language and formal restraint of "The Last Quatrain" has a devastating effect: showing that in sacrificing the privacy of her deepest grief and trauma-by making her son's funeral public, and open casket, for the sake of the greater good-Mamie Till has given enough.

In her conspicuous silence regarding the photograph of Till's corpse, Lorde also uses restraint and silence-the power of that which is not said-to formalize a resonant gesture of respect. As Jacqueline Goldsby's work illuminates, the significance of Till's death can be traced as much to the technological representation of the racial violence as to the murder itself (Goldsby 1996, 2006). Emerging at a critical moment in the development of mass media, the image proliferated in a way that was profoundly distinctive to its historical moment, and was consequently impossible to ignore. By indicating an issue of Jet magazine lying - discarded—on a subway car in New York City in the summer of 1955, we who know the history can be reminded of the image of Till's body and its effect in a way that is at once arresting but does not perpetuate its vulgar circulation. Like Brooks's poem that notices Till's mother's grief without reproducing the personal sacrifice of its being made available for public consumption, Lorde's withholding-while-evoking of Till's corpse indicates a similar artistic desire: to represent, without exploitation; to formalize, without objectification; to assert the fact of horror, without causing additional psychic or emotional violence. 
A few pages prior to the omission of Till's photo in her reference to Jet, Lorde describes the unequalled strength that she eventually gained from accepting her own unavoidable "difference," both racial and sexual. She follows this description with a glimpse of the pain caused by such recognition of her own invisibility, meted out by the racial community with which she should have felt at home:

But in this plastic, anti-human society in which we live, there have never been too many people buying fat Black girls born almost blind and ambidextrous, gay or straight. Unattractive, too, or so the ads in Ebony and Jet seemed to tell me. Yet I read them anyway, in the bathroom, on the newsstand, at my sister's house, whenever I got a chance. It was a furtive reading, but it was an affirmation of some part of me, however frustrating.

If nobody's going to dig you too tough anyway, it really doesn't matter so much what you dare to explore. I had already begun to learn that when I left my parents' house. (Lorde 1982, p. 210)

Thus, we understand Jet magazine as an ambivalent power in her life, but one that communicates vital information to her about what it must "mean" to be both black and a woman. Unable to find herself reflected in the pages of Jet, her first avenue to self-understanding becomes the woman-loving erotic: a way to knowledge that is not only unacceptable in the larger black community of the time, but by all indications invisible. Zami is not only a story of a young lesbian woman's journey to sexual self-realization and empowerment, but also a story of that same woman's journey toward and through her own "blackness." Not by accident, the physical/psychic breakdown that grips Audre toward the end of the narrative and leads her to self-actualization occurs in the fall of 1956, one year after Till's death and coinciding with the frightening and thrilling beginning of what we now call the modern Civil Rights Movement.

The coupling of Till's absence-on the train, where she leaves Jet magazine of summer 1955 behind-and the mention of Audre's secret poetry also implies by association a distinction between what can and cannot be expressed through prosaic language, and aligns the event with the silent, invisible place in which her racial identity developed during these years of her life. Audre receives images and information of what "blackness" means from her largely estranged relatives, and then symbolically leaves it behind, in the totemic form of Jet magazine, on the train that carries her back downtown. Audre digests this racial information in a way kept secret not only from her primarily white social group, but from herself as well. As a result, we are given the impression of a young woman who is at once enmeshed in and alienated from what her racial identity is supposed to mean. The unacceptable nature of her sexuality makes "blackness" feel like a deeply personal experience, embodied though the twinned experiences of shame and fear that attach to it. There is a strong sense in this brief passage from Zami that there is much more to be said; as the narration shifts from Jet, we are promptly, though subtly, directed to her poetry: "When I mentioned at the library that I wrote poetry ..." (Lorde 1982, p. 210)

Like a guide, Lorde uses prose here to point to things which lie off the page but are integral to understanding the world in which Zami takes place. Though the Till murder is excluded from the "biomythography," Lorde memorializes the event in "Afterimages," written one year prior to the publication of Zami. The long free verse poem weaves together several themes: Till's murder and its legacy, which Lorde describes as her "inheritance;" his mother's grief, and by extension that of all black women; the silence, subjugation, and willful ignorance of a poor white woman at the crux of the crime; the whites' "secret relish" of the pictorial details of the violence; and the power of traumatic images to remain indelible in the consciousness. ${ }^{11}$ It is this "secret relish" that Lorde senses in whites' reception of the photograph that horrifies her almost as much as the image itself.

11 In her essay on Zami, Cassie Premo (Steele 2000) discusses the traumatic memory's resistance to narration: "As we have seen [in other examples of "witness" poetry], traumatic memories are not in narrative form but are flashes, images, or 
Further, the representation and dissemination of the photograph of Till's corpse appears here inseparable from the very act of violence it represents, such that his murder-both in spite of and because of its very publicity-becomes an intensely personal experience: at once connecting Lorde to historical time, but also alienating her into the isolation of trauma. The memory of Till's death becomes so personal to Lorde, in fact, that her memory of it cannot be rendered in the "thinking" form of prose language that she reserves for her identity-affirming memoir. As an emblem of the other events of the Civil Rights Movement that would similarly be omitted from Lorde's narrative of self, Lorde's decision to render such racial history in poetic form rather than prose consequently has a broader significance all its own.

At the time of Till's murder, Audre did not seek out the photograph; instead, its mass publication found her wherever she went. It was an assault to her senses, and caused her young eyes, starving for information and affirmation, to look away. In "Afterimages," Lorde writes:

[ ... ]learning to survive

where there is no food

my eyes are always hungry

and remembering

however the image enters

its force remains.

[... ]

His broken body is the afterimage of my 21st year

When I walked through a northern summer

Eyes averted from each corner's photography

Newspapers protest posters magazines

[...]

And wherever I looked that summer

I learned to be at home with children's blood

with savored violence

with pictures of Black broken flesh

used crumpled up discarded

lying amid the sidewalk refuse

like a raped woman's face. (Lorde 1992)

By excluding the event from her memoir, but including it, and indicating its powerful personal significance, in her poetry, Lorde draws a distinction between what can and cannot be expressed through prose, but also between that which belongs within and without the form of a narrative about racial identity. By refusing to share the grief and trauma of involuntarily encountering the Till photographs that summer of 1955, in her memoir Lorde asserts a refusal just as politically significant as the self-fashioning project itself: to keep a sense of emotional privacy in the harsh midst of an un-chosen political life.

\footnotetext{
'afterimages', that remain with the survivor, repeating themselves within her, assaulting her from within". (p. 76) Steele goes on to discuss the power and necessity of telling the story of such memories, that such telling allows the writer to "go beyond surviving to living". Her discussion, however, does not address the absence of such specific "witnessing" in Lorde's "biomythography," which has a tacit claim to be written for the sake of doing just what Steele describes. Steele concludes her essay by exhorting the value of "witnessing": "... [W] must choose to witness or not ... To refuse these choices is, as we have seen, to be a 'false witness', to contribute to the continuation, to the perpetuation of violent destruction".
} 
Though the personal may always be political, refusing an expectation to expose one's most private feelings of grief in prose form can be a political act all its own. But the decision also equates Till's death with that of a deeply private and embodied, experience; "racial memory" here becomes indistinguishable from the embodiment of emotion. That is, despite its highly public nature, the death of Emmett Till and the proliferation of its representation in the media emerges in Lorde's work as an experience so deeply personal that it cannot appear anywhere but in the emotional and ostensibly less mediated language of her poetry. For Lorde, prose is for "knowing," while poetry is the form appropriate for the emotions, rooted as they are not in the rational mind but in the body and the soul. In this scheme, racial history does indeed appear to be "centered within."

In an interview with Adrienne Rich, Lorde discussed this distinction between poetry and prose in her work, indicating a trepidation toward putting feelings into prose form before they have grown into clear pieces of understood information:

For some reason, the more poetry I wrote, the less I felt that I could write prose. ... [C]ommunicating deep feeling in linear, solid blocks of print felt arcane, a method beyond me.... I was also afraid of it because there were inescapable conclusions or convictions I had come to about my own life, my own feelings that defied thought. And I wasn't going to let them go. I wasn't going to give them up. They were too precious to me. They were life to me. But I couldn't analyze or understand them because they didn't make the kind of sense I had been taught to expect through understanding. There were things I knew and couldn't say. And I couldn't understand them.... [or] write prose about them.... All I had was the sense that I had to hold on to these feelings and that I had to air them in some way. ${ }^{12}$

At the close of the interview, Lorde admits:

I don't know how I just wrote the long prose piece I have just finished [Zami], but I just knew that I had to do it.

Adrienne: That you had to understand what you knew and also make it available to others.

Audre: That's right. Inseparable process now. But for me, I had to know I knew it first-I had to feel. (Lorde 1992, p. 109)

For Lorde, feeling precedes knowing, and moreover is the birth mother of knowledge:

This is poetry as illumination, for it is through poetry that we give name to those ideas which are- until the poem-nameless and formless, about to be birthed, but already felt. That distillation of experience from which true poetry springs births thought as dream births concept, as feeling births idea, as knowledge births (precedes) understanding. ${ }^{13}$

Poetic language is the first and only pathway by which crucial information can travel out of herself and into the world. Poetic language is intimately reflective of her primary source of knowledge, the wordless fluidity of intuitive wisdom and sensual experience. By Lorde's description, prosaic language presumes an ownership on her part as the writer, a claim to the fixed nature of what is being expressed. To put knowledge primarily baszed on intuition and feeling into prose form too soon would be to "lose" it.

The "biomythography" is not, however, written exclusively in prose form. Many of the most deeply felt passages are written in language more poetic than prosaic, doubly distinguished from the bulk of the text by the use of italics. Thus, it is not that Lorde simply omits poetic language from her memoir, but rather, and more precisely, that she chose to represent the contemporaneous events of

12 Lorde, "An Interview: Audre Lorde and Adrienne Rich," in Sister Outsider, pp. 87-88.

13 Lorde, "Poetry Is Not a Luxury", in Sister Outsider, pp. 36-39. 
racial history both in poetic form, and elsewhere. The choice makes the most publicized events of the Civil Rights Movement-i.e., the most racially significant historical events of her life-feel less public, and more private; less political, and more personal. The choice renders racial identity less as phenomena contingent upon historical and political meaning, and more as phenomena of the body and soul. As such, through literary genre, Lorde can wordlessly assert racial identity as a spiritual truth: a timeless experience of the private heart, even while marking its historical significance in the sociopolitical world at large.

\section{The Self-Structuring Power of Silence}

Prior to the absence of Till's death, we are prepared for understanding the power of that which remains unsaid by a life story that thematizes silence from its very beginning. Though Lorde would frequently warn against the violence enacted by imposed and accepted forms of personal silencing, particularly for anyone who identifies as other, a close reading of her memoir reveals a much more ambivalent relationship to the effects and negotiation of the force of information withheld. This complexity is best embodied in the imprint and presence of Audre's mother, Linda. Lorde states as much at the outset, in a description that applies not only to the ambivalence toward one's parents, but the struggle to negotiate oneself in relation to hegemony: "when I hear my mother in my words I have to stop and reconsider what I am saying". (Lorde 1982, p. 14)

The silence under which young Audre suffers produces a sharp but amorphous fear of her own uncontrollable, natural tendencies and capabilities:

As a child, the most horrible condition I could contemplate was being wrong and being discovered. Mistakes could mean exposure, maybe even annihilation. In my mother's house, there was no room in which to make errors, no room to be wrong. (Lorde 1982, p. 58)

Information is repeatedly kept from Audre throughout her childhood by her parents: information about race, emotional survival, sexuality. This becomes more than a neutral silence, but a willful withholding that Audre understands better incrementally as she grows. Not surprisingly, anger and silence consequently erupt between Audre and her mother as she becomes a teenager. Audre becomes the victim of her own silence, but also learns the power that such silence can wield. In a later essay, Lorde would write:

For we have been socialized to respect fear more than our our own needs for language and definition, and while we wait in silence for that final luxury of fearlessness, the weight of that silence will choke us. ${ }^{14}$

As a child perceiving the racist attitudes of whites but deprived of the language with which to apprehend it, Audre believed that she was "different because I was me". (Lorde 1982, p. 82) Thus, in place of what should have been an understanding of herself as belonging to a marginalized and oppressed racial group, victimized by a racism that had nothing to do with her, the power of her parents' silence became translated in a child's mind into the opposite: an interpretation of racist attitudes as indicating a personal failing on her part, and therefore inculcating a personal shame. That is, the experience of racial identity that should have indicated nothing more than an ascribed group membership, rooted in historical contingency, instead became a painfully alienating experience of private, painfully individualized identity.

As the story of Audre's life unfolds, this practice of quietly living inside of herself becomes both a blessing and curse. Such a sense of difference causes her pain, but also forces Audre to turn to inward and to discover that claiming her true self will be a journey that she must create, through whatever means necessary. For the sake of survival at home, Audre spends her childhood perfecting the art of

14 Lorde, "Poetry is not a Luxury," in Sister Outsider, p. 44. 
getting by as if she knows, as if she has knowledge that she has not been told. Though cultivated out of necessity, such intuitive ways of knowing become invaluable in a world in which she was "never meant to survive". ${ }^{15}$ In her wordlessness and obscured vision as a young girl, Audre turns inward and realizes that she must discover herself on terms of her own design. When her sisters withhold their stories from her, Audre averts her gaze from the painful longing and opens up a place of new creation all her own. One morning, listening to the sounds of her sleeping family, Audre makes a momentous decision: "Right then and there, before anyone else woke up, I decided to make a story of my own". (Lorde 1982, p. 48)

As she grows, Audre begins to harness the power of silence by employing it herself, rather than merely as a compelled response to the intuited directives of others. In addition to these fecund periods of quiet, Audre's self-creation becomes not only self-driven but also collaborative, as she allows others of her choosing to inscribe onto her information about who she is-particularly when she finds herself unable to do so on her own. And, in perhaps the most cynical and yet most practically useful deployment of strategic silence, she learns early the art of faking it 'til you make it, and even to "cherish the façade":

I learned how to feel and ask questions afterward. I learned how to first cherish the façade and then the fact of being an outlaw. (Lorde 1982, p. 86)

As Audre strikes out on her own, she employs her own silence as a way of preserving a self that has not yet found its voice. Like her reluctance to write in prose, she does not give words to what she is feeling until she feels that she understands it, so that she can be speaking from a place of power. In one of the most poignant examples, Audre's silence about her abortion becomes a painful way of protecting her truth by creating the self she wants to be in others' eyes:

The abortion had left me with an additional sadness about which I could not speak, certainly not to these girls who saw my house and my independence as a refuge, and seemed to think that I was settled and strong and dependable, which, of course, was exactly what I wanted them to think. (Lorde 1982, p. 119)

In her first sexual relationship with a woman, Audre remains quiet, allowing Ginger to imagine her in a way that will make possible the courageous act of making love: when Ginger imagines her as a "slick kitty from the city," Audre "held [her] peace" and did her best to live true to the wished-for projection (Lorde 1982, p. 129). Ginger, a black woman, thus helps name both who Audre already is and who she is destined to become. Repeatedly asking her in these scenes, "cat got your tongue?", Lorde reminds us of Audre's outward silences and foreshadows Audre's ultimate experience of self-inscription with her final partner of Zami, Afrekete. With Ginger, Audre uses silence and her honed skills of nonverbal perception to reach a new, though insufficient, level of self-knowledge and self-realization. Unable to name herself alone, she allows, and tacitly encourages, Ginger to do the work for her. Ginger continued to "buil[d] up an incredible mythology" (Lorde 1982, p. 133) about Audre, as Audre became more and more dependent on her for company, love, food, and shelter. Audre's continued silence allows, and tacitly encourages, Ginger to assume her identity as a lesbian. Audre is empowered, however superficially, by Ginger's creation of her, and her strategic silence allows this radically collaborative personal development to occur.

The façade does not, however, last. Though doing her best to maintain the persona of the "slick kitty from the city" who knows all she needs to know, Audre's contrived identity is shaken and challenged when Ginger reveals to her the tip of an iceberg of withheld racial information in the form of American history:

15 Lorde, "The Transformation of Silence into Language and Action," in Sister Outsider, p. 42. 
It wasn't her fault I was feeling so out of sorts all of a sudden, so disjointed. Crispus Attucks. Something had slipped out of place. ... I had spent four years at Hunter High School, supposedly the best public high school in New York City ... . Yet, I never once heard the name mentioned of the first man to fall in the american revolution, not ever been told that he was a Negro. What did that mean about the history that I had learned? ... 'What's wrong with you today? Cat got your tongue?' [Ginger asked.] (Lorde 1982, pp. 132-3)

Ginger is not only an agent of Audre's sexual realization, but also inadvertently dislodges a small boulder of deep racial recognition that builds intensity, becoming an avalanche upon her as Zami approaches its conclusion.

Making love with Ginger allows a wordless, authentic self within Audre to come out, distinct from the fabricated "slick kitty from the city". Being with Ginger provides her with a racial affirmation she has painfully lacked. Neither woman can quite own herself, however, and each becomes "invested in denial" for their own reasons. Ginger provides Audre with two sources of sustenance which she will eventually discover to be her most important: her sexuality and her racial consciousness. Ginger is her first affirmation of both, and her first experience of the two being compatible. The experience prefigures the final destination/discovery of Audre's authentic self in the mythical Afrekete. Zami is not only a story of Audre's journey toward/within a woman-loving erotic self but is just as powerfully a striving to reconcile this sexuality with her "blackness," a sense of self that becomes physical, essentialized, by being conjoined with the erotic.

Toward the end of Zami, as the American Civil Rights Movement begins in historical time, the person who developed on the page into the poet who would later become Audre Lorde withholds from her readers her reflections and experiences of these public, political events. In the form of the memoir, the omissions function less as evasions, and more as evidence of Audre's attempt to navigate a complex space between the personal and the political, during a period in which the power of the pairing was beginning to both cohere in some ways, and yet also break apart. That is to say, though the personal may indeed be political, particularly for women, when the political becomes merely personal, its power as such has been evacuated.

Through historical omissions such as Till's death, Lorde re-enacts and re-purposes her mother's averted eyes and withheld words in the story of Zami. While her mother withholds from Audre the "language of race" out of a sense of maternal protection, the tensions produced by an openly racist society infiltrates their home nonetheless. Though expressly hungry for this missing language, Lorde employs a similar active silence in Zami. We see how Audre's ultimate breakdown occurs due to the power of a silence so devastating that its contributing factors are withheld from her readers as she was withholding them from herself. The racial silence Audre inflicts upon herself during the years covered in Zami is intensified by a narrative which creates a false world, one in which the narrator mimics Linda Lorde and averts her eyes from the "racial" events of the time, compounding her readers' experience of Audre's own interior isolation regarding how to understand herself in the changing scheme of a post-Jim Crow but nonetheless highly racialized world.

Though Lorde describes and alludes to lengthy discussions with her white lesbian friends as often being engaged with many of the popular leftist causes of the time, even becoming more pronounced at the start of 1955, the current events concerning race relations apparently do not arise. Audre's averted gaze as described in "Afterimages" is a way of life, real and metaphorical, and, though painful, provided for even sharper honing of her powers of intuition-particularly around the hoped-for recognition of a shared identity:

Sometimes we'd pass Black women on Eighth Street—-the invisible but visible sisters—or in the Bag or at Laurel's, and our glances might cross, but we never looked into each other's eyes. We acknowledged our kinship by passing in silence, looking the other way. Still, we were always on the lookout, Flee and I, for that telltale flick of the eye, that certain otherwise prohibited openness of expression, that definiteness of voice which would suggest, I think she's gay. After all, doesn't it take one to know one? (Lorde 1982, p. 180) 
Though invisible in the text, the escalation of the American Civil Rights Movement by the end of 1955 was on a parallel course with Audre's increasingly frustrated racial silences. Just as the activism of the 1950s began to erupt, Audre's own feelings of racial invisibility within and without had begun to destroy her. Lorde recalls not only "blinding headaches" during this time, but also an almost involuntary act of self-mutilation when she scalds herself with boiling water. Symbolically, the injury is later covered by bracelets brought to her by her mother from Grenada, the home of Audre's own racial identity (Lorde 1982, pp. 233, 236). In the same year, Audre's struggle with maintaining a racial identity within the white "gay girl" community is increasingly stifled by the girls' refusal to admit racial difference, and their insistence on a shared, colorblind exclusion from mainstream society.

By the fall of 1955, Audre "seldom spoke," preferring intuitive communication instead (Lorde 1982, pp. 214-5). She began therapy and struggled against emotions she neither understood nor wanted to feel. Her poetic writing and dreaming intensified, delving deeper into an interiority that lay beyond words. As a precursor to the racial awakening she achieves with and through Afrekete, Audre finally speaks aloud about her racial identity to her friends, if indirectly, in the confrontation with Dottie at Laurel's (Lorde 1982, p. 223). Soon thereafter, as her constrictive social group appears to fall away piece by piece, Audre finds her actualized self in finding love with another.

When Audre begins her experience with Afrekete, the narrative language becomes almost entirely poetic. Though the two women briefly share their feelings about race and loving women, most of what passes between them remains unspoken (Lorde 1982, p. 250). Their exchanges occur in the deeper places of power and sensuality which lie beyond formal language, and to which Audre returns throughout the story for strength and survival. Beyond the prosaic discussions with her white lesbian friends, wordless understanding and union between Afrekete and Audre become the place where race consciousness and lesbian eroticism meet one another, accept one another, and merge into the truest conception of herself that Audre has found.

Thus, racial identity and sexual identity reconcile, so that both become equally essentialized, embodied, experiences of life. At the close of their affair, the larger Civil Rights struggle asserts its (non)presence again, as Afrekete returns to her home in the American south. Elsewhere, Lorde described her conflicting feelings of moral obligation and physical anxiety about going south during the 1960s, as well as her sense of the south as being home to a certain kind of nurturing, and empowering racial authenticity. In an interview with Adrienne Rich, Lorde describes her early intentions to join the Freedom Riders in 1961, followed by her fears about being asked to teach at Tougaloo in Mississippi: "I was terrified to go south" ${ }^{16}$ Lorde goes on to describe her experience at Tougaloo as giving her a speaking voice for the first time, and a new, affirming relationship with other African Americans. (90)

\section{Conclusions}

Perhaps Zami stands as an intentionally incomplete story, one that omits simmering information that could not, at the time of its writing, be "understood" enough to be expressed in prose form. After all, the form of language one chooses cannot be separated from the truth one is aiming to speak:

For those of us who write, it is necessary for us to scrutinize not only the truth of what we speak, but the truth of that language by which we speak it. (Lorde 1984)

In this light, Zami appears as an even more profound telling of an African American woman's ongoing journey to and from herself, and one that reflects a battle that was perhaps Lorde's toughest, one in which the silences are as powerful as the words spoken.

As such, much of the orchestrated silence employed in Zami works less as an evasion of history and more as a method of self-preservation, signaling the alienation and invisibility she found as an African American lesbian in the majority of her predicted audience: an intellectual feminist realm still,

16 (Lorde 1984, p. 89). 
at the time of Zami's writing, largely comprised of white women. ${ }^{17}$ She keeps her experience of racial identity and racialized self-formation relatively close to her chest, employing what Patricia Hill Collins describes as the "hidden consciousness" of African American women, the selective silences that allow space for "the 'inside' ideas that allow black women to cope with and, in many cases, transcend the confines of intersecting oppressions of race, class, gender, and sexuality" (Collins 2000, p. 98).

On the one hand, Zami stands apart from characterizations of the neoliberal memoir as a celebration of individualism through the exaltation of personal affect and emotion, by depicting a deeply collaborative development of self through various engagements and negotiations of racial and sexual identity. Audre does not create herself out of whole cloth, but rather learns how to be who she is by learning both how to be with others, but also how to be strategically silent. Audre's experience with Afrekete culminates in an almost purely poetic, italicized rendering of reconciliation between the racial and the erotic, such that the paths of her developing sources of sustenance and survival intersect. In this mythical creation/discovery, a nurturing, evocative sensuality is blended with lesbian eroticism and affirmative black identity in such a way that it creates a home for Audre's wandering sense of self-and perhaps for Lorde's wandering sense of formal ambivalence. Here, silence indicates not invisibility, but survival.

But as Lorde has demonstrated in Zami, and asserted frequently in her speeches, essays, and poetry, such strategic withholding is a way of surviving — not of truly living. By writing a pointedly political memoir but omitting one of the most significant historical events of its timeline, Lorde's "biomythography" perhaps inadvertently follows the pull of the neoliberal turn that would have the significance of history be reduced to the feelings of an individual.

Funding: This research had no external funding.

Conflicts of Interest: The author declares no conflict of interest.

\section{References}

Alabi, Adetayo. 2005. Telling Our Stories: Continuities and Divergences in Black Autobiographies. New York: Palgrave Macmillan.

Andrews, William L. 1986. To Tell a Free Story: The First Century of Afro-American Autobiography, 1760-1865. Urbana: University of Illinois Press.

Brooks, Gwendolyn. 1960. The Bean Eaters. New York: Harper.

Buell, Lawrence. 2016. Literary Transcendentalism: Style and Vision in the American Renaissance. Ithaca: Cornell University Press.

Collins, Patricia Hill. 2000. Black Feminist Thought. New York: Routledge.

Franklin, V. P. 1995. Living Our Stories, Telling Our Truths: Autobiography and the Making of the African American Intelectual Tradition. New York: Scribner.

Gilmore, Leigh. 2017. Tainted Witness: Why We Doubt What Women Say About Their Lives. New York: Columbia U P.

Goldsby, Jacqueline. 1996. The High and Low Tech of It: The Meaning of Lynching and the Death of Emmett Till. The Yale Journal of Criticism 9: 245-82. [CrossRef]

Goldsby, Jacqueline. 2006. A Spectacular Secret: Lynching in American Life and Literature. Chicago: University of Chicago Press.

Griffin, Farrah Jasmine. 1995. Who Set You Flowin': The African-American Migration Narrative. New York: Oxford University Press.

Keating, AnaLouise. 1996. Inscribing 'Black', Becoming ... Afrekete. In Women Reading Women Writing: Self-Invention in Paula Gunn Allen, Gloria Anzaldua and Audre Lorde. Philadelphia: Temple University Press.

Lorde, Audre. 1982. Zami: A New Spelling of My Name. Berkeley: The Crossing Press.

Lorde, Audre. 1984. Sister Outsider. Berkeley: The Crossing Press.

17 Ana Louise (Keating 1996) also notes the significance of Lorde's silence, as both racially self-preserving and as an echo of her mother's attempts at protection, though she does not note the absence of Till's murder form the text. 
Lorde, Audre. 1992. Undersong: Chosen Poems Old and New Revised. New York: W.W. Norton \& Co.

Lorde, Audre, Marge Piercy, Fran Moira, and Lorraine Sorrel. 1982. Interview: Audre Lorde: Lit from within. Off Our Backs 12: 2-3, 11.

McKay, Nellie. 1995. The Narrative of Self: Race, Politics, and Culture in Black American Women's Autobiography. In Feminisms in the Academy. Edited by Domna Stanton and Abigail Stewart. Ann Arbor: University of Michigan Press, pp. 75-100.

Metress, Christopher. 2003. 'No Justice, No Peace': The Figure of Emmett Till in African American Literature. MELUS 28: 87-103. [CrossRef]

Michaels, Walter Benn Michaels. 2017. The Trouble with Diversity: How We Learned to Love Identity and Ignore Inequality. New York: Holt.

Moody, Joycelin. 2001. Sentimental Confessions: Spiritual Narratives of Nineteenth-Century African American Women. Athens: University of Georgia Press.

Rubin, Anne Sarah. 1996. Reflections on the Death of Emmett Till. Southern Cultures 2: 45-66. [CrossRef]

Smith, Valerie. 2008. Emmett Till's Ring. Women's Studies Quarterly 36: 151-61. [CrossRef]

Smith, Rachel Greenwald. 2015. Affect and American Literature in the Age of Neoliberalism. Cambridge: Cambridge University Press.

Steele, Cassie Premo. 2000. 'My eyes are always hungry and remembering': Audre Lorde and the Poetry of Witness. In We Heal from Memory: Sexton, Lorde, Anzaldua, and the Poetry of Witness. New York: Palgrave.

Till-Mobley, Mamie, and Christopher Benson. 2003. Death of Innocence: The Story of the Hate Crime That Changed America. New York: Random House.

Warren, Kenneth W. 2011. What Was African American Literature? Cambridge: Harvard University Press.

Whitfield, Stephen J. 1988. A Death in the Delta: The Story of Emmett Till. New York: Free Press.

Wilson, Anna. 2001. The Visible Margin: Audre Lorde as I/Icon. In Persuasive Fictions: Feminist Narrative and Critical Myth. Lewisburg: Bucknell University Press.

Worden, Daniel. 2017. The Memoir in the Age of Neoliberalism. In Neoliberalism and Contemporary Literary Culture. Edited by Mitchum Huehls and Rachel Greenwald Smith. Baltimore: Johns Hopkins University Press.

(C) 2019 by the author. Licensee MDPI, Basel, Switzerland. This article is an open access article distributed under the terms and conditions of the Creative Commons Attribution (CC BY) license (http://creativecommons.org/licenses/by/4.0/). 